\title{
PENGARUH STRES KERJA, EMPLOYEE ENGAGMENT, DAN KEDISIPLINAN TERHADAP KINERJA DENGAN KEPUASAN KERJA SEBAGAI VARIABEL INTERVENING PADA KARYAWAN CV. KARYA MANUNGGAL SEMARANG
}

\author{
Lianasari, Paulus Wardoyo, Djoko Santoso \\ adyalk@gmail.com,**djoko_hw@usm.ac.id*** \\ Pascasarjana - Program Magister Manajemen-Universitas Semarang
}

\begin{abstract}
The research is conducted on companies that produce gloves both for domestic and abroad. Production companies like these require a lot of employees and high performance. But the company's work has decreased, so the company's target can not be achieved. Not achieving the target company is allegedly influenced by several factors, such as job stress, discipline, employee engagement, and job satisfaction. The purpose of this research is to analyze the influence of work stress, discipline and employee engagement on performance with job satisfaction as intervening variable. The respondent in this study as many as 247 employees. Data analysis technique used is SEM (Structural equation Modeling) with LISREL program Version 8.80. The result of analysis shows that job stress and employee engagement have an effect on job satisfaction, job stress and employee engagement also affect to employee performance. There is no effect of discipline on job satisfaction or performance..

Keywords: Job stress, Discipline, Employee Engagement, satisfaction and Employee performance

\section{ABSTRACT}

Penelitian ini dilakukan pada perusahaan yang memproduksi sarung tangan baik untuk dalam negeri maupun luar negeri. Perusahaan produksi seperti ini membutuhkan karyawan yang banyak serta kinerja yang tinggi. Namun hasil kinerja perusahaan mengalami penurunan, sehingga target perusahaan tidak dapat tercapai. Tidak tercapainya target perusahaan ini diduga dipengaruhi oleh beberapa faktor, diantaranya adalah stres kerja, kedisiplinan, employee engagement, dan kepuasan kerja. Tujuan dari penelitian ini adalah untuk menganalisis pengaruh stres kerja, kedisiplinan dan employee engagement terhadap kinerja dengan kepuasan kerja sebagai variabel intervening. Responden dalam penelitian ini sebanyak 247 karyawan. Teknik analisis data yang digunakan adalah SEM (Structural equation Modelling) dengan program LISREL Versi 8.80. Hasil analisis menunjukkan bahwa stres kerja dan employee engagement berpengaruh terhadap kepuasan kerja, stres
\end{abstract}


kerja dan employee engagement juga berpengaruh terhadap kinerja karyawan. Tidak ada pengaruh kedisiplinan terhadap kepuasan kerja dan kinerja.

Kata Kunci : Stres kerja, Kedisiplinan, Employee Engagement, kepuasan dan Kinerja Karyawan.

\section{PENDAHULUAN}

Tercapainya perusahaan yang maju dan terus dapat berkembang adalah keinginan setiap pengusaha dalam perusahaan. Kemajuan sebuah perusahaan tidak lepas dari kemajuan karyawannya dalam bekerja. Bagaimana karyawan bekerja dan berperilaku dalam perusahaan akan menentukan nasib sebuah perusahaan di masa yang akan datang. Para karyawan diharapkan menjalankan semua tugas-tugasnya dengan baik.

Sumber daya manusia yang baik diharapkan dapat memberi hasil yang baik bagi perusahaan. Pada kenyataannya pimpinan perusahaan masih banyak menemukan kendala dalam perusahaan. Hasil produksi yang tidak mencapai target, sehingga perusahaan harus mengadakan lembur karena jam kerja yang ada tidak menyelesaikan target perusahaan. Kualitas yang dikeluhkan buyer dari standar yang ditetapkan, dan berimbas pada keterlambatan pengiriman barang yang menjadikan kekhawatiran pimpinan perusahaan akan adanya klaim dan menimbulkan kerugian bagi perusahaan .

Demi tercapainya hasil yang maksimal, perusahaan akan mengoptimalkan kinerja pada karyawan supaya mendapatkan hasil yang diharapkan.Tekanan bisa berupa peraturan yang ketat, baik berupa jam kerja yang lebih lama, tambahan jam lembur, sehingga tingkat kelelahan fisik juga bertambah pada karyawan. Naiknya harga-harga kebutuhun pokok dalam pemenuhan kebutuhan hidup yang tidak seimbang dengan kenaikan pendapatan, tambahan bonus, tuntutan target dan beban kerja karyawan yang tinggi dalam bekerja. Situasi ini seringkali memicu terjadinya stres kerja. Efek psikologis yang paling sederhana dan jelas dari stres kerja adalah turunnya kepuasan kerja dan produktivitas kerja. Menurut Handoko (2008) bahwa stres kerja dan kepuasan kerja dapat mempengaruhi kinerja karyawan itu sendiri. Dengan meningkatnya stres kerja tersebut maka produktivitas karyawan akan terganggu atau menurun (Harianto, Wiguna, Rakhmad, 2008). Selanjutnya Dewi, Bagia, Susila (2014) menyatakan bahwa ada pengaruh signifikan antara stres kerja terhadap kinerja karyawan.

Chandra (2012) juga menyatakan bahwa stres kerja secara parsial mempunyai pengaruh yang signifikan terhadap kinerja. Pengaruh stres kerja terhadap kinerja adalah negatif, artinya bahwa ketika stres kerja rendah maka kinerja tinggi. Demikian pula Fida , Nasir, Ahmad ( 2011) juga menyatakan bahwa stres berhubungan negatif dengan kepuasan kerja karyawan. Naqvi, et, al (2013) menyatakan stres kerja menyebabkan hal negatif dalam produktivitas karyawan yang artinya apabila tingkat stres meningkat maka mengurangi produktivitas karyawan. Stres kerja berpengaruh negatif terhadap kinerja pegawai artinya semakin tinggi tingkat stres kerja pegawai akan memberi 
dampak negatif dalam peningkatan kinerja dan kepuasan kerja berpengaruh positif terhadap kinerja pegawai (Nur, 2013).

Namun hal yang berbeda disampaikan Sutrisno (2012) bahwa stres kerja tidak berpengaruh signifikan pada kinerja karyawan. Begitu juga dengan penelitian Adawiyah dan Siswanto (2015) yang menyatakan bahwa stres kerja tidak berpengaruh secara langsung terhadap kinerja karyawan yang berarti tidak ada pengaruh antara variabel stres kerja terhadap kinerja karyawan, sehingga meskipun stres kerja yang dibebankan tinggi tidak akan berpengaruh terhadap kinerja karyawan.

Suatu keterikatan, loyalitas dan komitmen juga diperlukan supaya karyawan dapat bekerja secara optimal. Kinerja karyawan dipengaruhi oleh berbagai hal, salah satunya sikap karyawan terhadap pekerjaannya yaitu rasa senang, kenyamanan, antusias dalam bekerja. Engagement menjadi semakin penting kaitannya dengan kinerja karyawan, karena semakin tinggi tingkat keterikatan karyawan, semakin baik kinerja karyawan dan pada gilirannya semakin baik kinerja perusahaan (Widjaja, Kristiani, Purnamasari, 2014). Menurut Arwinda Pritami (2016) menyebutkan bahwa 7 dari 10 karyawan merupakan karyawan yang tidak memiliki rasa keterikatan dengan perusahaan, Karyawan yang memiliki keterikatan yang rendah 4 kali lebih mungkin berhenti dari pekerjaannya ketimbang mereka yang memiliki keterikatan yang tinggi.

Menurut Macey et al (2009) rasa engaged adalah suatu keterikatan, keterlibatan, komitmen, keinginan untuk berkontribusi, rasa memiliki (sense of belonging), loyalitas dan rasa bangga terhadap pekerjaan dan juga perusahaannya. Apabila perusahaan memiliki karyawan yang rasa keterikatannya tinggi akan membuat karyawan betah untuk bekerja ditempat tersebut dan kepuasannya akan meningkat ( Rahmawati, 2013 ).

Seseorang yang telah memutuskan untuk bekerja dalam suatu perusahaan, namun belum sepenuhnya menjalankan semua tugas-tugasnya maka ia dikatakan belum memiliki engagement atau engaged terhadap pekerjaannya. Karyawan yang memiliki employee engagement yang tinggi akan bekerja dengan antusias, sangat menikmati pekerjaannya , bersedia untuk lembur dengan senang hati, datang lebih awal, terus berusaha meningkatkan kualitas diri untuk memajukan perusahaan. Komitmen emosional karyawan pada organisasi dan tujuannya disebut employee engagement ( Kruse, 2012).

Siti Haerani (2004) menyatakan bahwa employee engagement berpengaruh positif dan signifikan terhadap kinerja. Tinggi rendahnya kinerja departemen ditentukan atau dipengaruhi oleh kuat lemahnya employee engagement karyawan. Keterlibatan karyawan menghasilkan produktivitas yang lebih tinggi, peningkatan kualitas produksi, kuantitas produksi, layanan pelanggan, peningkatan penjualan dan inisiatif manajemen.

Menurut penelitian Cheema, Akram, Javed (2015) menemukan bahwa karyawan yang terlibat sepenuh hati dan bekerja keras, hal itu menariknya untuk 
menjadi lebih cerdas dan terampil terhadap organisasi. Mereka juga menyatakan bahwa penelitiannya menunjukkan hubungan yang signifikan antara employee engagement dengan pelanggan dan kepuasan karyawan. Employee engagement menunjukan pengaruh positif pada kinerja , keterlibatan mereka juga memiliki hubungan positif dengan komitmen karyawan (Avolio, et al , 2004).

Kedisiplinan karyawan dalam bekerja juga diduga mempengaruhi keoptimalan kinerja karyawan. Menurut penelitian Listianto dan Setiaji (2005) ada yang mempengaruhi kinerja karyawan yaitu disiplin kerja. Denis, Peggy, dan Jantje (2014) menunjukkan bahwa disiplin kerja dan kualitas kerja berpengaruh positif terhadap prestasi kerja. Arsyenda (2013) juga menyatakan disiplin kerja mempunyai pengaruh terhadap kinerja pegawai, disiplin kerja sangat berpengaruh terhadap kinerja. Penelitian tersebut juga sesuai dengan Mangkunegara dan Octorend (2015) yang menyatakan disiplin kerja, motivasi kerja, kepuasan bekerja berpengaruh positif dan signifikan terhadap kinerja. Penelitian dengan hasil yang berbeda dinyatakan oleh Sadiyo (2014) bahwa disiplin kerja tidak berpengaruh terhadap kinerja . Arianto (2013) menemukan hal yang sama bahwa lingkungan kerja dan kedisiplinan kerja tidak berpengaruh pada kinerja. Hasil temuan diatas menunjukkan adanya inkonsistensi hasil temuan penelitian stres kerja berpengaruh terhadap kinerja dan sekelompok peneliti yang lain menyatakan bahwa stres kerja tidak berpengaruh terhadap kinerja. Begitu juga dengan penelitian kedisiplinan, kedisiplinan kerja berpengaruh terhadap kinerja dan beberapa peneliti yang lain menyatakan bahwa kedisiplinan tidak berpengaruh terhadap kinerja.

\section{Tujuan Penelitian}

Berdasarkan latar belakang diatas, secara ringkas penelitian bertujuan untuk 1) Menganalisis pengaruh stres kerja terhadap kepuasan kerja dan kinerja karyawan. 2) Menganalisis pengaruh kedisiplinan kerja terhadap kepuasan kerja dan kinerja karyawan. 3) Menganalisis pengaruh Employee Engagement terhadap kepuasan kerja dan kinerja karyawan.

\section{TELAAH PUSTAKA}

\section{Kinerja Karyawan}

Menurut Chandra (2012) kinerja merupakan gabungan perilaku dengan prestasi dari apa yang diharapkan dan pilihannya atau bagian syarat-syarat tugas yang ada pada masing-masing individu dalamm organisasi. Sedangkan menurut Mangkunegara (2002) kinerja dapat didefinisikan sebagai hasil kerja secara kualitas dan kuantitas yang dapat dicapai oleh seorang karyawan dalam melaksanakan tugas sesuai dengan tanggung jawab yang diberikan kepadanya.

Mondy (2008) mengemukakan bahwa manajemen kinerja adalah proses berorientasi tujuan yang diarahkan untuk memastikan bahwa proses-proses keorganisasian ada pada tempatnya untuk memaksimalkan produktivitas para karyawan , tim, dan akhirnya organisasi. Rivai dan Basri (2005) juga 
menjelaskan bahwa kinerja adalah hasil atau tingkat keberhasilan seseorang secara keseluruhan selama periode tertentu dalam melaksanakan tugas dibandingkan dengan berbagai kemungkinan, seperti standart, target atau sasaran atau kriteria yang telah ditentukan terlebih dahulu telah disepakati bersama.

\section{Kepuasan Kerja}

Menurut Setiawan dan Ghozali ( 2006) kepuasan kerja adalah Kondisi menyenangkan atau secara emosional positif yang berasal dari penilaian seseorang atas pekerjaannya atau pengalaman kerjanya. Suatu perasaan positif tentang pekerjaan seseorang yang merupakan hasil dari sebuah evaluasi karakteristiknya (Robbins dan Judge, 2008). Kepuasan kerja adalah sikap atau perasaan puas dan tidak puas karyawan terhadap hasil penilaian dari pekerjaan yang telah dilakukannya. Hal ini sejalan dengan pendapat Kaswan (2012) dan Handoko (2001) memandang kepuasan kerja sebagai perasaan puas atau tidak puas karyawan terhadap pekerjaan mereka, perasaaan itu akan tampak dari sikap karyawan terhadap pekerjaan dan dilingkungan kerjanya. Dimensi kepuasan kerja yang digunakan dalam penilitian ini mengacu pada pendapat Kaswan (2012) dan Luthans (2006) diantaranya pekerjaan itu sendiri, gaji, kesempatan promosi, rekan kerja, dan kondisi kerja.

\section{Stres Kerja}

Stres kerja merupakan ketidakmampuan karyawan menghadapi tuntutan kerja karena karyawan tidak memiliki kemampuan sebagaimana yang dituntut pekerjaan. Stres kerja merupakan kondisi mental maupun fisik yang mempengaruhi produktifitas, efektifitas, kesehatan, dan kualitas kerja (Chandra, 2012). Stres kerja adalah fenomena bahwa setiap karyawan menghadapi pekerjaan dan menanganinya secara berbeda-beda sesuai dengan caranya sendiri, yang pada dasarnya adalah ketidaksesuaian antara kemampuan individu dan permintaan organisasi (Pediwal,2011)

Munandar (2004) menjelaskan stres yang dialami karyawan saat ini menjadi masalah yang besar jika dilihat dari akibat yang ditimbulkan. Turnover yang tinggi pada organisasi merupakan salah satu akibat dari stres kerja pada karyawan, hal ini jika tidak segera diatasi maka akan menimbulkan kerugian finansial pada organisasi. Menurut Andraeni (2005) mendefinisikan stres sebagai suatu tanggapan dalam menyesuaikan diri yang dipengaruhi oleh perbedaan individu dan proses psikologis, sebagai konsekuensi dari tindakan lingkungan, situasi atau peristiwa yang terlalu banyak mengadakan tuntutan psikologis dan fisik seseorang. Dengan demikian dapat diambil kesimpulan bahwa stres kerja timbul karena tuntutan lingkungan dan tanggapan setiap individu dalam menghadapinya dapat berbeda.

\section{Disiplin Kerja}

Kedisiplinan adalah kesadaran dan kesediaan seseorang mentaati semua peraturan instansi/perusahaan dan norma-norma sosial yang berlaku (Fathoni, 
2006). Menurut Simamora (2004) bahwa kedisiplinan adalah prosedur yang mengoreksi atau menghukum bawahan karena melanggar peraturan atau prosedur. Displin merupakan bentuk pengendalian diri karyawan dan pelaksanaan yang teratur menunjukkan tingkat kesungguhan tim kerja di dalam sebuah organisasi. Tindakan disiplin yang efektif terpusat pada perilaku karyawan yang salah, tidak pada karyawan sebagai pribadi.

Mangkunegara dan Octorend (2015) juga menjelaskan bahwa disiplin kerja adalah alat yang digunakan oleh para manajer untuk berkomunikasi dengan karyawan sehingga mereka bersedia untuk mengubah perilaku sebagai upaya untuk meningkatkan kesadaran tiap orang, dan kemauan untuk mematuhi semua peraturan dan norma-norma perusahaan yang berlaku sosial. Sehingga dapat disimpulkan bahwa disiplin kerja merupakan upaya dari organisasi manajemen perusahaan untuk melaksanakan atau mengeksekusi aturan atau peraturan yang harus ditaati oleh semua karyawan tanpa terkecuali.

\section{Employee Engagement}

Employee engagement adalah kekuatan ilusif (komitmen terhadap organisasi, kebanggaan terhadap pekerjaan, pengerahan waktu dan tenaga, passion dan ketertarikan) yang memotivasi pegawai untuk performansi ke tingkat yang lebih tinggi (Concelmen,2004). Menurut Gibbons (2004) employee engagement menjadikan karyawan untuk mengerahkan kinerjanya melebihi apa yang diharapkan perusahaan. Pengertian lain juga disampaikan oleh Robinson, et, al (2004) bahwa employee engagement adalah sikap positif yang dimiliki karyawan terhadap nilai-nilai dan tujuan organisasi, menunjukkan kesadaran karyawan akan konteks bisnis dan adanya kesediaan untuk bekerja dengan rekan kerja untuk meningkatkan kinerja dalam pekerjaan dan demi kepentingan organisasi.

\section{METODOLOGI PENELITIAN}

Metodologi penelitian ini menjelaskan metode yang dilakukan dalam penelitian. Jenis data dalam penelitian ini menggunakan data primer yaitu data yang diperoleh secara langsung dari sumber asli atau tanpa melalui media perantara dari obyek penelitian. Data primer yang digunakan dalam penelitian ini diperoleh melalui kuisioner dengan skala interval yang diberikan pada sampel yang telah ditentukan yaitu dari karyawan CV. Karya Manunggal Semarang.

\section{Jenis Penelitian}

Jenis penelitian yang digunakan dalam penelitian ini adalah jenis explanatory yaitu menjelaskan pengaruh antar variabel tertentu melalui pengujian hipotesis. Penelitian ini digunakan untuk menguji hipotesis dan menjelaskan pengaruh antar variabel yaitu variabel bebas (stres kerja, disiplin kerja dan Employee Engagement) terhadap variabel terikat (Kinerja Karyawan) bagi karyawan CV. Karya Manunggal Semarang. Data primer dapat diperoleh langsung dari obyek penelitian. data ini diperoleh secara langsung dari sumber utama dan diperoleh melalui observasi wawancara kuisioner. 


\section{Populasi Penelitian}

Populasi adalah wilayah generalisasi yang terdiri atas obyek/subyek yang mempunyai kuantitas dan karakteristik tertentu yang ditetapkan oleh peneliti untuk dipelajari dan kemudian ditarik kesimpulannya (Sugiyono : 2010). Populasi dalam penelitian ini adalah seluruh pegawai yang bekerja di CV Karya Manunggal Semarang yang berjumlah 247 orang.

\section{Sampel Penelitian}

Seluruh anggota populasi dijadikan responden. Penelitian ini menggunakan metode sensus yang artinya seluruh karyawan memiliki kesempatan untuk menjadi responden. Jumlah responden dalam penelitian ini sebanyak 247 responden

\section{Metode Pengumpulan Data}

Metode pengumpulan data dalam suatu penelitian ilmiah dimaksudkan memperoleh bahan-bahan yang relevan akurat dan terpercaya teknik pengumpulan data yang digunakan dalam penelitian ini adalah kuisioner dengan Interval Scale. Menurut Ferdinand (2014) skala interval adalah alat pengukur data yang dapat menghasilkan data yang memiliki rentang nilai yang mempunyai makna, walaupun nilai absolutnya kurang bermakna. Data interval tergolong data kontinum yang mempunyai tingkatan yang lebih tinggi lagi dibandingkan dengan data ordinal karena mempunyai tingkatan yang lebih banyak lagi, data interval menunjukkan adanya jarak antara data yang satu dengan yang lainnya (Sugiyono, 2009).

\section{Metode Analisis}

Pada penelitian ini digunakan analisis dengan persamaan struktural atau lebih dikenal dengan SEM (Structural Equation Modeling), dimana setiap variabel terikat (Y) secara unik keadaannya ditentukan oleh seperangkat variabel bebas (X). SEM adalah sebuah model statistik yang memberikan perkiraan perhitungan dari kekuatan hubungan hipotesis diantara variabel dalam sebuah model teoristik, baik langsung atau melalui variabel antara ( intervening or moderating ), SEM adalah model yang memungkinkan pengujian sebuah rangkaian atau network model yang lebih rumit (Haryono, 2017).

\section{Analisis Faktor Konfirmatori (CFA)}

Analisis Factor Confirmatory (CFA), adalah teknik yang digunakan dalam SEM untuk menentukan apakah variabel indikator benar-benar membentuk variabel laten yang diteliti. Analisis SEM melalui dua tahapan yaitu model pengukuran dan model struktural.

\section{Uji Kecocokan (Goodness of Fit Test)}

Untuk mendapatkan variabel yang cocok (fit) atau signifikan digunakan dalam model persamaan Persamaan Struktural Lengkap ( PSL), PSL dapat digunakan untuk membuat analisis koefisien regresi , uji hipotesis dan lain lain maka persamaan struktural lengkap harus melalui proses uji GOF ,tujuannya 
adalah untuk memahami secara komprehesif terhadap variabel laten yang akan diteliti akhirnya menghasilkan definisi variabel secara konseptual. Variabel secara konseptual ini disebut konstruk.

\section{Uji Hipotesis}

Ketepatan fungsi regresi sampel dalam menaksir nilai aktual dapat dinilai dengan godness of fit-nya, bukan F-test. Untuk pengujian partial tetap digunakan $\mathrm{t}$ test. T hitung dalam SEM adalah CR (Criticalo Ratio). H0 ditolak jika CR $\geq 1,96$ pada level $\alpha 5 \%$. Mengingat analisis SEM adalah gabungan dari analisis regresi dan jalur, pengujian cukup dengan GOF sebagai pengganti F-test dalam analisis regresi dan jalur. Jika hasil uji GOF dalam SEM telah fit, maka secara otomatis (tersirat) model simultan/struktural telah fit.

\section{Program Lisrel 8.80}

Penelitian ini akan dianalisis menggunakan program LISREL versi 8.80 , Lisrel merupakan salah satu program komputer yang dapat mempermudah analisis untuk menyelesaikan masalah- masalah yang tidak dapat diselesaikan oleh alat analisis konvensional. Jika data tidak normal maka analisis SEM dengan metode Maksimum Likelihood ( ML) tidak dapat digunakan . Oleh karenanya, program Lisrel 8.80 mampu melakukan analisis dengan pendekatan Robust Maksimum likelihood (RML). Program Lisrel 8.80 saat ini sudah lebih canggih karena jika data yang akan diolah ternyata tidak berdistribusi normal, secara otomatis program Lisrel 8.80 akan men-default pada posisi analisis RML.

\section{Analisis Responden}

\section{ANALISIS DATA DAN PEMBAHASAN}

Penelitian ini menggunakan alat ukur berupa kuisioner untuk memperoleh data dari setiap variabel yang terdapat pada model penelitian. Data pada penelitian ini diperoleh dari responden yang merupakan karyawan CV. KARYA MANUNGGAL dari berbagai bagian dalam perusahaan. Berikut adalah data profil karyawan CV.KARYA MANUNGGAL :

Tabel 1 Data Profil karakteristik karyawan CV.KARYA MANUNGGAL

\begin{tabular}{|llrr|}
\hline No & Profil & Jumlah & persentase \\
\hline 1. & Jenis Kelamin & 224 & $91 \%$ \\
& Perempuan & 23 & $\underline{9 \%}$ \\
\hline & Laki-laki & & \\
\hline $\mathbf{2 .}$ & Usia & $\mathbf{2 8}$ & $\mathbf{1 1 \%}$ \\
& $\leq \mathbf{2 0}$ Tahun & $\mathbf{5 2}$ & $\mathbf{2 1 \%}$ \\
& $\mathbf{2 1}-\mathbf{3 0}$ Tahun & $\mathbf{1 0 2}$ & $\mathbf{4 1 \%}$ \\
$\mathbf{3 1}-\mathbf{4 0}$ Tahun & $\mathbf{5 9}$ & $\mathbf{2 4 \%}$ \\
$\mathbf{4 1}-\mathbf{5 0}$ Tahun & $\mathbf{6}$ & $\mathbf{3 \%}$ \\
\hline
\end{tabular}




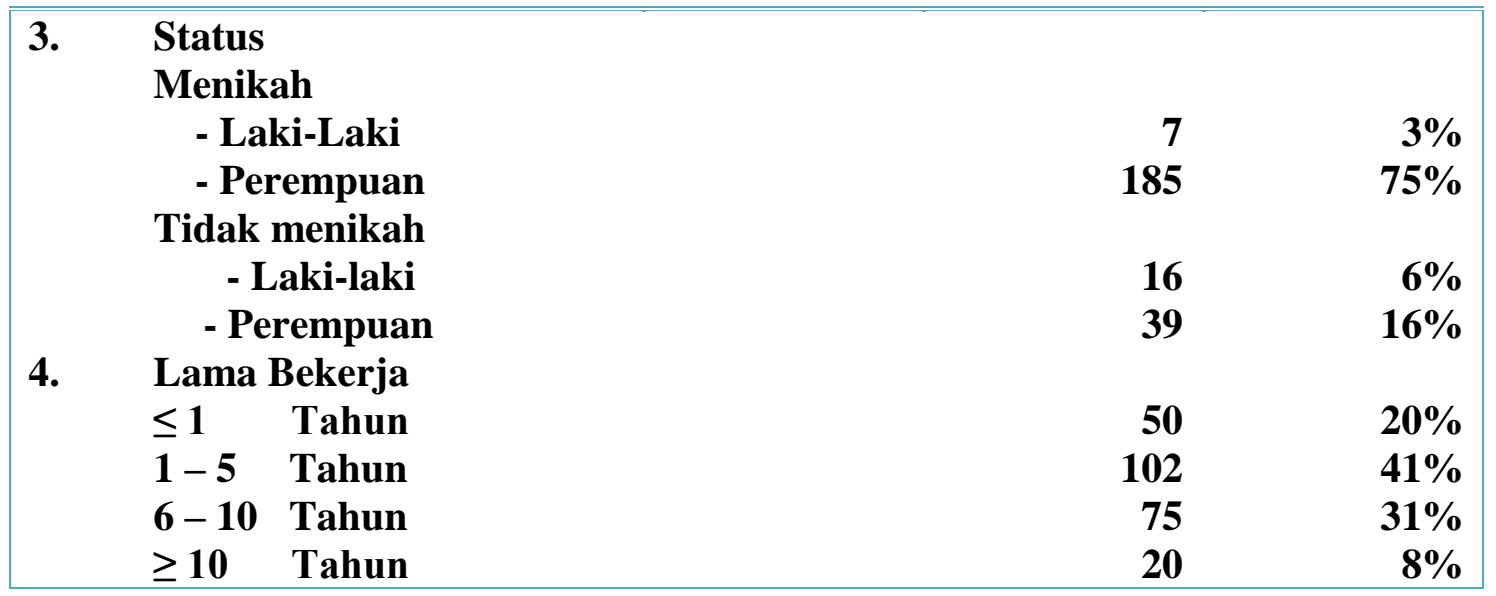

Sumber : data primer yang telah diolah, 2017

Dari data karyawan tersebut dapat diketahui bahwa sebagian besar karyawan CV.KARYA MANUNGGAL adalah perempuan dan sebagian besar telah menikah. Sebagian besar karyawannya juga telah bertahan cukup lama dalam perusahaan antara 1 sampai 10 tahun. Sebagian kecil ada yang masih bertahan lebih dari 10 tahun. Karyawan terbanyak pada rentang umur 31 sampai 40, dimana usia ini masih merupakan usia produktif.

\section{Analisis Structural Equation Modeling (SEM)}

Tujuan akhir dari Structural Equation Modeling (SEM) adalah untuk mendapatkan model struktural. Pada dasarnya SEM tidak digunakan untuk membentuk sebuah teori kausalitas, tetapi untuk menguji kausalitas yang sudah ada teorinya. Secara umum analisis SEM melalui dua tahapan yaitu model pengukuran dan model struktural (Haryono,2017).

\section{Analisis Faktor Konfirmatori (Confirmatory Factor Analysis/ CFA)}

Model struktural bertujuan untuk mendapatkan konstruk atau variabel laten yang fit. Untuk mendapatkan variabel yang fit digunakan uji CFA. Dalam penelitian ini pengukuran suatu konstruk dilakukan secara tidak langsung melalui indikator-indikatornya. Indikator dengan loading factor yang tinggi memiliki kontribusi yang lebih tinggi untuk menjelaskan konstruk latennya. Sebaliknya pada indikator dengan loading factor rendah memiliki kontribusi yang lemah untuk menjelaskan konstruk latennya. Pada sebagian besar referensi bobot faktor sebesar 0,50 atau lebih dianggap memiliki validasi yang cukup kuat untuk menjelasakan konstruk laten (ghozali,2008). Setelah melalui perbaikan model hasil analisis faktor konfirmatori pada penelitian ini dapat dilihat pada tabel 2 berikut : 


\section{Tabel 2 Hasil Analisis Faktor Konfirmatori}

\begin{tabular}{l|c}
\multicolumn{1}{c}{$\quad$ Indikator } & Faktor Loading \\
\cline { 2 - 2 } -Kebosanan & \\
-Bersedih & 0,72 \\
Variabel Disiplin & 0,54 \\
- Mematuhi peraturan & 0,81 \\
- Tepat waktu & 0,77 \\
- Merapikan Alat & 0,59 \\
Variabel EE & \\
-Fokus & 0,78 \\
-Berbicara positif & 0,83 \\
Variabel Kepuasan & \\
-Keselamatan Kerja & 0,72 \\
-Jaminan kesehatan & 0,75 \\
Variabel Kinerja & \\
-Mencapai target & \\
-Kemampuan kerjasama & 0,71 \\
-Melaporkan masalah & 0,53 \\
& 0,58 \\
&
\end{tabular}

Sumber : Hasil pengolahan data, 2017

Dari tabel 2 dapat dilihat hasil pengujian faktor konfirmatori pada variabel stres, variabel disiplin, variabel employee engagemenet, variabel kepuasan dan variabel kinerja menunjukkan bahwa indikator sudah mempunyai loading factor $\geq$ 0,5 sehingga kita bisa melihat hasil output Goodness of fit statistics. Apabila hasilnya masih belum fit, maka kita harus memperbaiki model sampai mendapatkan hasil yang memenuhi Goodness of fit dan bisa dilakukan analisis lebih lanjut.

\subsubsection{Uji Kesesuaian SEM}


Teknik analisis data menggunakan Structural Equation Modelling (SEM) yang dioperasikan melalui program Linear Structural Relationship (LISREL). Adapun software yang digunakan adalah LISREL versi 8.80. LISREL merupakan salah satu program komputer yang dapat mempermudah analisis untuk menyelesaikan masalah-masalah yang tidak dapat diselesaikan oleh alat analisis yang konvensional (Sugiarto, 2006). Lisrel juga memiliki kemampuan untuk mengkonfirmasi dimensi-dimensi dari sebuah konsep atau faktor yang sangat lazim digunakan dalam manajemen serta kemampuannya untuk mengukur pengaruh hubungan yang secara teoritis ada (Ferdinand,2005).

Sebuah model dapat diterima atau ditolak adalah dengan melihat dari Goodness of fit. Model persamaan struktural pada penelitian ini menghasilkan sebuah model dengan Goodness of fit yang telah terpenuhi atau dapat diterima. Ringkasan Goodness of fit dalam penelitian ini dapat dilihat dari tabel 4.13 dibawah ini :

Tabel 3 Hasil Uji Kesesuaian Model

\begin{tabular}{|c|c|c|c|}
\hline Goodness of Fit & $\begin{array}{l}\text { Cutt of } \\
\text { Value }\end{array}$ & Hasil & $\begin{array}{l}\text { Keteranga } \\
\text { n }\end{array}$ \\
\hline df (Degrees of Freedom) & $\geq 0$ & 44 & Good Fit \\
\hline GFI ( Goodness of Fit Index) & $\geq 0,90$ & 0,93 & Good Fit \\
\hline NFI ( Normed Fit Index) & $\geq 0,90$ & & Good Fit \\
\hline NNFI (Non-Normed Fit Index & $\geq 0,90$ & 0,94 & Good Fit \\
\hline CFI (Comparative Fit Index ) & $\geq 0,90$ & 0,94 & Good Fit \\
\hline RFI (Relative Fit Index) & $\geq 0,90$ & $\begin{array}{l}0,90 \\
091\end{array}$ & Good Fit \\
\hline $\begin{array}{l}\text { RMSEA ( Root Mean Square Error of } \\
\text { Approximation) }\end{array}$ & $\leq 0,08$ & $\begin{array}{c}0,91 \\
0,074\end{array}$ & Good Fit \\
\hline AGFI ( Adjusted Goodness of Fit Index ) & $\geq 0,90$ & 0,88 & $\begin{array}{l}\text { Marginal } \\
\text { Fit }\end{array}$ \\
\hline
\end{tabular}

Sumber : Hasil pengolahan data, 2017

Berdasarkan hasil uji Goodness of Fit (GOF), Sebagian besar persyaratan telah memenuhi standar cutt-of value sehingga model layak untuk dianalisis lebih lanjut. Berdasarkan tabel 4.13 dapat diketahui bahwa perhitungan Goodness of Fit Index (GFI) pada model regresi sebesar 0,93, hasil ini menunjukkan hasil yang baik, karena mendekati nilai satu. Semakin mendekati 0 maka semakin tidak layak model. Hasil Normed Fit Index (NFI) sebesar 0,94 menunjukkan good fit. NFI mempunyai nilai berkisar 0 sampai 1 , nilai NFI $\geq 0,90$ menunjukkan good fit. Hasil Non-Normed Fit Index (NNFI) adalah sebesar 0,94, yang berarti good fit. Hasil Comparative Fit index (CFI) juga menunjukkan good fit, yaitu sebesar 0,96. Hasil Relative Fit Index juga menunjukkan hasil good fit, yaitu sebesar 0,91. Hasil Root Mean Square error of Approximation (RMSEA) sebesar 0,074 yang kurang dari 0,08 menunjukkan kriteria yang baik dalam mengukur nilai penyimpangan parameter model dengan matriks kovarian model. RMSEA merupakan ukuran yang mencoba memperbaiki 
kecenderungan statistic chi-square menolak model dengan jumlah sampel yang besar. Nilai RMSEA antara 0,05 sampai 0,08 merupakan ukuran yang dapat diterima. Hasil uji empiris RMSEA cocok untuk menguji model konfirmatori atau competing model strategy dengan jumlah sampel besar (Ghozali, 2013).

Hasil Adjusted Goodness of fit (AGFI) adalah sebesar 0,88, yang artinya AGFI telah memenuhi uji kelayakan model karena berada pada marginal fit. Seperti GFI, nilai AGFI berkisar antar 0 sampai 1 dan nilai AGFI $\geq 0,90$ menunjukkan good fit. Sedangkan $0,80 \leq \mathrm{AGFI} \leq 0,90$ sering disebut marginal fit. AGFI, NFI, NNFI, CFI, dan RFI merupakan ukuran kecocokan inkremental yang biasanya digunakan untuk mengevaluasi SEM. Ukuran kecocokan inkremental membandingkan model yang diusulkan dengan model dasar (Baseline model) yang sering disebut null model ( independence model) dan saturated model. Null model merupakan model yang tingkat kecocokan model-data paling buruk. Saturated model merupakan tingkat kecocokan model-data paling baik. Konsep kecocokan inkremental akan menempatkan tingkat kecocokan model-data berada diantara null model dan saturated model. Semakin dekat ke saturated model akan semakin baik tingkat kecocokannya (Haryono, 2017).

GFI, RMSEA merupakan uji kecocokan absolut untuk menentukan derajat prediksi model keseluruhan (model struktural dan pengukuran) terhadap matrik korelasi dan kovarian. Ukuran ini mengandung ukuran-ukuran yang mewakili sudut pandang overall fit. Model dikatakan layak jika paling tidak salah satu metode uji kelayakan model terpenuhi. Apabila uji kelayakan model bisa memenuhi lebih dari satu kriteria kelayakan model, model analisis konfirmatori akan jauh lebih baik daripada hanya satu yang terpenuhi. Selain Uji kecocokan absolut dan uji kecocokan inkremental masih ada satu lagi uji kecocokan parsimoni untuk mengukur goodness of fit. Uji kecocokan parsimoni yaitu untuk melakukan adjusment terhadap pengukuran fit dan dapat diperbandingkan antar model dengan jumlah koefisien yang berbeda. Dari berbagai ukuran kecocokan parsimoni , ukuran yang digunakan untuk mengevaluasi SEM dalam penelitian ini adalah sebagai berikut :

Tabel 4 Hasil Uji Kecocokan Parsimoni

\begin{tabular}{|c|c|c|c|c|}
\hline GOF & Model & Independence & Saturated & Keterangan \\
\hline $\begin{array}{l}\text { AIC ( Akaike } \\
\text { information } \\
\text { Criterion }\end{array}$ & 170,89 & 1634,67 & 156 & Good Fit \\
\hline $\begin{array}{c}\text { CAIC ( Akaike } \\
\text { information } \\
\text { Criterion }\end{array}$ & 324,21 & 1688,79 & 507,73 & Good Fit \\
\hline
\end{tabular}

Sumber : Hasil pengolahan data, 2017

Hasil Uji kecocokan parsimoni AIC dan CAIC menunjukkan good fit. Model AIC sebesar 170,89, nilai AIC dari model yang mendekati nilai saturated AIC menunjukkan good fit. Nilai CAIC juga mendekati nilai saturated AIC, sebesar 324,21, yang menunjukkan good fit. Secara keseluruhan , berdasarkan uji Goodness 
of Fit yang dilihat dari tiga pengukuran yaitu absolut, incremental dan parsimony tersebut model dalam penelitian ini dapat menghasilkan model yang baik. Setelah model yang terbaik dapat dihasilkan, selanjutanya dapat dianalisis dengan menggunakan ukuran signifikansi dan besarnya pengaruh variabel eksogen terhadap variabel endogen. Hasil pengukuran hubungan signifikansi antar variabel dapat diketahui dari output model dengan melihat besarnya t-values yang dihasilkan. Adapun model yang dihasilkan oleh model persamaan struktural (SEM) dengan tvalue dapat dilihat pada Gambar1

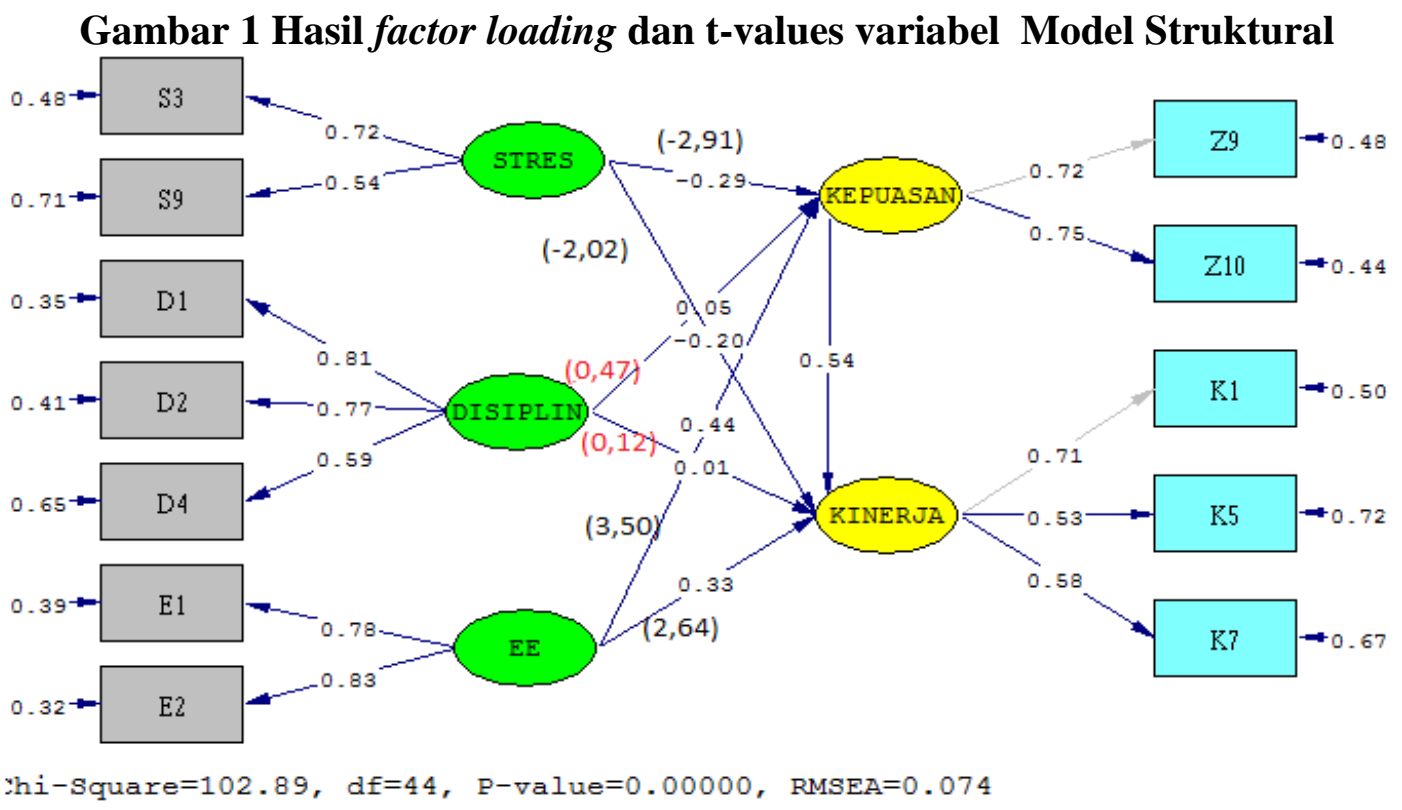

Sumber : Hasil pengolahan data penelitian, 2017

Gambar 1 menunjukkan bahwa terdapat koefisien jalur yang berwarna merah yaitu disiplin terhadap kepuasan sebesar 0,47 dan disiplin terhadap kinerja sebesar 0,12 yang nilainya lebih kecil daripada nilai kritis yaitu 1,96 , artinya nilai tersebut tidak signifikan. Dalam gambar 4.1 juga menunjukkan hasil perhitungan statistik terhadap data lapangan yang memenuhi tingkat signifikansi yang disyaratkan oleh SEM lebih besar dari nilai 1,96 yaitu variabel stres terhadap variabel kepuasan sebesar - 0, 291, variabel stres terhadap variabel kinerja sebesar - 2,02, variabel EE terhadap variabel kepuasan sebesar 3,50 dan variabel EE terhadap variabel kinerja sebesar 2,64. Tanda negatif pada t-values variabel stres menunjukkan bahwa variabel stres berpengaruh negatif.

\section{Pengujian Hipotesis}

Pengujian hipotesis yang diajukan dalam penelitian dapat dilihat dari besarnya nilai kritis uji-t statistik. Batas limit untuk menerima atau menolak hipotesis yang diajukan adalah $\pm 1,96$, dapat diartikan apabila nilai t berada pada rentang nilai - 1,96 dan 1,96 maka hipotesis satu (H1) ditolak atau dengan kata lain menerima hipotesis 
nol (H0). Jika lebih dari 1,96 maka hipotesis satu (H1) diterima dan hipotesis (H0) ditolak. Berikut adalah tabel nilai kritis hasil uji-t statistik berdasarkan output dengan Lisrel Versi 8.80 .

Tabel 5 Pengaruh Antar Variabel Laten

\begin{tabular}{|c|c|c|c|c|}
\hline No & Hipotesis & Krta & Hsl & Kesimpulan \\
\hline 1 & $\begin{array}{l}\text { Stres kerja berpengaruh } \\
\text { terhadap kinerja karyawan }\end{array}$ & $\geq 1,96$ & $-2,02$ & $\begin{array}{l}\text { H1 diterima, artinya terdapat } \\
\text { pengaruh stres kerja terhadap } \\
\text { kinerja karyawan }\end{array}$ \\
\hline 2 & $\begin{array}{l}\text { Stres kerja berpengaruh } \\
\text { terhadap kepuasan kerja }\end{array}$ & $\geq 1,96$ & $-2,91$ & $\begin{array}{l}\text { H1 diterima, artinya terdapat } \\
\text { pengaruh stres kerja terhadap } \\
\text { kinerja karyawan }\end{array}$ \\
\hline 3 & $\begin{array}{l}\text { Kedisiplinan kerja } \\
\text { berpengaruh terhadap } \\
\text { kinerja }\end{array}$ & $\geq 1,96$ & 0,12 & $\begin{array}{l}\text { H1 ditolak H0 diterima, artinya } \\
\text { tidak terdapat pengaruh } \\
\text { kedisiplinan terhadap kinerja } \\
\text { karyawan }\end{array}$ \\
\hline 4 & $\begin{array}{l}\text { Kedisiplinan kerja tidak } \\
\text { berpengaruh terhadap } \\
\text { kepuasan kerja }\end{array}$ & $\geq 1,96$ & 0,47 & $\begin{array}{l}\text { H1 ditolak H0 diterima, artinya } \\
\text { tidak terdapat pengaruh } \\
\text { kedisiplinan terhadap kepuasan } \\
\text { karyawan }\end{array}$ \\
\hline 5 & $\begin{array}{l}\text { Employee Engagement } \\
\text { berpengaruh terhadap } \\
\text { kinerja karyawan }\end{array}$ & $\geq 1,96$ & 2,64 & $\begin{array}{l}\text { H1 diterima, artinya terdapat } \\
\text { pengaruh Employee Engagement } \\
\text { terhadap kinerja karyawan }\end{array}$ \\
\hline 6 & $\begin{array}{l}\text { Employee Engagement } \\
\text { berpengaruh terhadap } \\
\text { kepuasan karyawan }\end{array}$ & $\geq 1,96$ & 3,50 & $\begin{array}{l}\text { H1 diterima, artinya terdapat } \\
\text { pengaruh Employee Engagement } \\
\text { terhadap kinerja karyawan }\end{array}$ \\
\hline 7 & $\begin{array}{l}\text { Kepuasan kerja berpengaruh } \\
\text { terhadap kinerja karyawan }\end{array}$ & $\geq 1,96$ & 4,36 & $\begin{array}{l}\text { H1 diterima, artinya terdapat } \\
\text { pengaruh kepuasan kerja terhadap } \\
\text { kinerja karyawan }\end{array}$ \\
\hline
\end{tabular}

Sumber : Hasil pengolahan data penelitian, 2017

\section{PEMBAHASAN}

\section{Pengaruh Stres Terhadap Kinerja (H1)}

Hasil penelitian ini menunjukkan bahwa hipotesis 1 stres kerja berpengaruh terhadap kinerja, tanda negatif pada t-hitung menunjukkan bahwa stres berpengaruh 
negatif terhadap kinerja. Hal ini memperkuat penelitian yang telah dilakukan oleh Dewi, Bagia dan Susila (2014) bahwa ada pengaruh negatif dan signifikan stres kerja terhadap kepuasan kerja. Temuan penelitian ini juga mendukung penelitian Chandra (2012) bahwa hasil uji-t menunjukkan bahwa stres kerja secara parsial mempunyai pengaruh signifikan terhadap kinerja. Pengaruh stres kerja terhadap kinerja adalah negatif, artinya bahwa ketika stres kerja rendah maka kinerja tinggi, dan demikian pula sebaliknya. Indikator yang dapat menjelaskan stres adalah karyawan merasa bosan, yg artinya karyawan pada CV. KARYA MANUNGGAL mengalami kebosanan yang tinggi sebagai indikator yang menjelaskan variabel stres. Bosan adalah Keadaan dimana pikiran menginginkan perubahan, mendambakan sesuatu yang baru, dan menginginkan berhentinya rutinitas hidup dan keadaan yang monoton dari waktu ke waktu (Leksono, 2014).

Menurut Fisher (1998) menyatakan bahwa kebosanan di tempat kerja merupakan suatu hal alami yang akan dirasakan oleh setiap orang namun sebagian besar hal ini telah diabaikan oleh organisasi. Dalam mengerjakan pekerjaan yang berulang-ulang dapat menimbulkan kebosanan dan hilangnya konsentrasi dalam pekerjaan tersebut. Kebosanan yang terjadi pada waktu singkat tidak akan memberikan pengaruh namun kemungkinan buruk yang terjadi adalah bila berlangsung dalam jangka waktu yang lama. Hal ini dapat menyebabkan stres bagi karyawan dan berdampak pada penurunan kinerja. Indikator stres yang lain yang dapat dipertahankan untuk mendapatkan model yang baik adalah kesedihan.

Kesedihan adalah suatu emosi yang ditandai oleh perasaan tidak beruntung, kehilangan, dan ketidakberdayaan (Jellesma dan Vingerhoets, 2012) . Kesedihan dalam menjelaskan stres kerja menunjukkan bahwa karyawan mengalami tingkat kesedihan yang tinggi. Karyawan perlu mengatasi stres dalam bekerja, supaya mereka tetap menjaga kualitas dan kuantitas hasil produksinya. Pertanyaan terbuka yang diberikan pada responden, tentang bagaimana mereka mengatasi stresnya ketika bekerja adalah mendengarkan musik, jalan-jalan, minum kopi, kebelakang sebentar, bercanda dan tertawa, shalat, istirahat sejenak. Dari jawaban responden tersebut justru ditemukan bahwa cara mengatasinya stres nya sangat mengganggu waktu dan proses kerja produksi, karena pada produksi di perusahaan ini adalah produksi yang prosesnya kontinyu (bersambung) atau saling bekerja sama. Apabila ada yang tersendat pada setiap bagian akan mempengaruhi hasil produksi secara keseluruhan.

\section{Pengaruh Stres Terhadap Kepuasan Kerja}

Hipotesis yang ke-2 bahwa stres berpengaruh terhadap kepuasan karyawan juga terbukti, tanda negatif menunjukkan bahwa stres berpengaruh negatif pada kepuasan karyawan. Hasil penelitian ini sesuai dengan hasil penelitian sebelumnya yang dilakukan Mansoor,et al (2011) di Pakistan bahwa stres berpengaruh negatif terhadap kepuasan karyawan. Hasil penelitian Chandra (2012) juga membuktikan bahwa stres kerja berpengaruh terhadap kepuasan kerja. Seseorang yang mengalami tingkat stres yang tinggi, kepuasannya juga akan berkurang, namun seorang karyawan yang dapat 
mengatasi rasa stresnya dengan baik juga akan dapat meningkatkan kepuasannya terhadap pekerjaan. Hal ini dapat dilihat bahwa rata-rata kepuasan pada responden ini tinggi.

\section{Pengaruh Kedisiplinan Terhadap Kinerja Karyawan (H3)}

Hasil analisis hipotesa yang ke-3 bahwa kedisiplinan kerja tidak berpengaruh terhadap kinerja, t-hitung $\leq \mathrm{t}$-tabel sehingga $\mathrm{H} 1$ ditolak dan $\mathrm{H} 0$ menyatakan bahwa kedisiplinan tidak berpengaruh terhadap kinerja karyawan pada CV. KARYA MANUNGGAL. Hasil ini tidak mendukung penelitian Thaief, et al (2015) dan Anggraini, Wispandono dan Ismail (2015). Kedua penelitian sebelumnya tersebut menyatakan bahwa kedisiplinan berpengaruh terhadap kinerja. Namun, hasil temuan ini sesuai dengan beberapa penelitian yang menyatakan bahwa kedisiplinan tidak berpengaruh terhadap kinerja ( Utari, 2015), (Sadiyo, 2014) dan (Arianto, 2013) . Dilihat dari jawaban responden atas pertanyaan terbuka, ditemukan bahwa kedisiplinan karyawan adalah karena takutnya atau khawatirnya karyawan akan sanksi dan denda, bukan karena ingin meningkatkan kinerja. Denda yang harus dibayar dengan dipotong gaji menjadi salah satu alat yang efektif dalam mendisiplinkan karyawan. Karena itu karyawan yang bersikap disiplin atau tidak disiplin tidak begitu berpengaruh terhadap kinerja karyawan.

\section{Pengaruh Kedisiplinan Karyawan Terhadap Kepuasan Karyawan}

Hipotesis ke-4 dalam penelitian ini yaitu kedisiplinan berpengaruh terhadap kepuasan karyawan juga tidak terbukti. Nilai t-hitung lebih kecil dari CR (critical ratio) yang artinya $\mathrm{H0}$ diterima, maka Tidak ada pengaruh kedisiplinan terhadap kepuasan karyawan. Hasil penelitian Sadiyo (2014) dan Arianto (2013) juga membuktikan hasil yang serupa, bahwa kedisiplinan tidak berpengaruh terhadap kinerja karyawan. Indikator yang menjelaskan kedisiplinan dalam penelitian ini adalah kepatuhan terhadap peraturan, ketepatan waktu dan kedisiplinan dalam merapikan kembali alat-alat yang telah dipakai. Nilai t-hitung pada masing masing indikator menunjukkan $t$-value yang tinggi, yaitu kepatuhan terhadap peraturan, ketepatan waktu dan kedisiplinan dalam merapikan alat kembali. Angka indeks responden rata -rata juga menunjukkan kedisiplinan yang tinggi, namun itu tidak bisa membuktikan bahwa kedisiplinan pada karyawan CV.KARYA MANUNGGAL dapat mempengaruhi kinerjanya. Ternyata pertanyaan terbuka dari penelitian ini ditemukan bahwa penyebab kedisiplinan yang tinggi pada karyawan CV.KARYA MANUNGGAL karena bila karyawan tidak disiplin akan dikenakan denda. Dimana denda harus dibayar dari pemotongan gaji. Karyawan CV. KARYA MANUNGGAL merasa lebih tenang dengan disiplin, sehingga orientasinya berperilaku disiplin lebih karena kenyamanan. Sehingga karyawan memiliki disiplin yang tinggi atau rendah dalam perusahaan ini tidak akan mempengaruhi kepuasannya dalam bekerja.

\section{Pengaruh Employee Engagement Terhadap Kinerja Karyawan (H5)}

Hipotesis ke-5 dalam penelitian ini, bahwa Employee Engagement berpengaruh terhadap kinerja karyawan terbukti. Nilai t-hitung lebih besar dari nilai CR (critical ratio), maka $\mathrm{H} 0$ ditolak dan $\mathrm{H} 1$ diterima. Hasil penelitian ini sesuai dengan penelitian 
Haerani (2012), bahwa Employee Engagement berpengaruh positif terhadap kinerja. Penelitian ini juga mendukung penelitian Dajani (2015) bahwa Employee Engagement berpengaruh terhadap kinerja karyawan. Sulistyo (2013) mengemukakan hasil penelitiannya yang senada , bahwa Employee Engagement memiliki pengaruh yang besar terhadap kinerja karyawan karena bila karyawan telah sangat engaged dengan seluruh organisasi dan komponenya yang ada maka dapat dipastikan kinerja karyawan meningkat. Jawaban dari hasil pertanyaan terbuka kepada responden ditemukan bahwa tingkat engaged yang tinggi pada karyawan di perusahaan ini adalah karena faktor usia, 68\% usia karyawan di perusahaan ini berumur lebih dari 30 tahun, sehingga karyawan apabila keluar dari perusahaan merasa akan mengalami kesulitan dalam mencari pekerjaan yang baru. Beberapa karyawan juga menjawab bahwa mereka tidak tahu harus bekerja kemana, karena kurangnya ketrampilan dan merasa yang dia mampu hanya pekerjaan ini, hal ini membuat karyawan tetap bertahan di perusahaan ini. Tidak adanya pilihan lain membuat mereka berusaha untuk bekerja sebaik mungkin.

\section{Pengaruh Employee Engagement Terhadap Kepuasan Karyawan (H6)}

Hasil penelitian Rachmawati (2010) juga mendukung hasil penelitian hipotesa ke-6, bahwa Employee Engagement berpengaruh terhadap kepuasan kinerja. Hasil penelitian menunjukkan bahwa nilai t-hitung lebih besar dari nilai kritis maka $\mathrm{H} 0$ ditolak dan H1 diterima, artinya Employee Engagment berpengaruh terhadap kepuasan karyawan. Employee engagement karyawan CV.KARYA MANUNGGAL termasuk tinggi yang ditunjukkan dengan rata- rata angka indeks responden. Indikator yang menjelaskan variabel Employee engagement adalah fokus dalam pekerjaan dan berbicara positif, artinya karyawan memusatkan perhatian, pandangan dan pembicaraannya pada tugas yang dikerjakannya serta mampu berbicara baik terhadap atasan ataupun rekan kerjanya. Berbicara positif disini diartikan berbicara yang baik, tidak mengeluarkan kata-kata kotor atau kata yang mengandung penghinaan, merendahkan atau melecehkan. Ditemukannya jawaban atas pertanyaan terbuka kepada responden bahwa karyawan mudah mendapatkan ijin apabila ada keperluan juga membuat mereka lebih suka bertahan dalam perusahaan, sehingga kepuasan mereka terhadap perusahaan juga meningkat.

\section{Pengaruh Kepuasan Terhadap Kinerja Karyawan (H7)}

Hipotesa ke-7 dalam penelitian ini juga terbukti, nilai t-hitung lebih besar dari nilai kritisnya , maka $\mathrm{H} 0$ ditolak dan $\mathrm{H} 1$ diterima. Hasil penelitian membuktikan bahwa kepuasan berpengaruh terhadap kinerja. Hal ini sesuai dengan hasil penelitian Murti dan Srimulyani (2013) bahwa kepuasan kerja berpengaruh terhadap kinerja pegawai. Begitu juga dengan hasil penelitian Adawiyah dan Siswanto ( 2015) yang membuktikan bahwa kepuasan kerja terhadap kinerja karyawan menunjukkan pengaruh yang positif, artinya semakin tinggi kepuasan kerja yang dimiliki karyawan maka kinerja nya akan meningkat. Tingkat kepuasan pada CV. KARYA 
MANUNGGAL ditunjukkan dengan angka indeks yang menunjukkan kepuasan yang tinggi terhadap perusahaan tempatnya bekerja. Hasil temuan dari pertanyaan terbuka terhadap responden menunjukkan bahwa teman- teman yang baik membuat karyawan sangat puas bekerja di perusahaan ini. Mereka juga merasa puas karena jam kerja yang baik. Karyawan juga merasa tidak tertekan. Beberapa responden menjawab bahwa pekerjaan mereka tidak terlalu berat, tidak dipaksa, waktu ibadah terjamin gajinya mencukupi. Hal tersebut membuat karyawan mendapatkan kepuasan ketika bekerja di perusahaan ini. Namun variabel kepuasan bukan merupakan variabel pemediasi bagi stres kerja, kedisiplinan maupun employee engagement.

Dilihat dari jawaban atas pertanyaan terbuka karyawan diketahui bahwa banyak juga ditemukan bahwa kepuasan karyawan dalam perusahaan justru dapat menurunkan kinerja, seperti karyawan merasa puas karena tidak ada evaluasi kinerja dari atasan, dalam bekerja karyawan tidak terlalu dipaksa dan waktu ibadah yang terjamin. Artinya dalam kegiatan produksi karyawan bisa izin untuk ibadah dengan mudah, hal ini akan sangat mengganggu hasil produksi. Seharusnya waktu ibadah juga diatur waktunya oleh perusahaan. Tidak adanya evaluasi membuat karyawan bekerja lebih santai, karena merasa tidak terlalu dipaksa. Hasil banyak atau sedikit, mereka akan mendapatkan gaji yang sama. Sehingga, Karyawan kurang terpacu dan kurang merasa perlu bertanggung jawab terhadap hasil. Karyawan pada perusahaan ini banyak yang belum mendapat gaji sesuai UMR, dan karyawan sangat mengharapkan mereka digaji sesuai UMR. Namun penggajian sesuai UMR masih perlu dikaji lebih lanjut, mengingat antara masing masing karyawan dalam bekerja memberi hasil yang jauh berbeda. Karena puasnya karyawan bekerja pada perusahaan ini, karyawan mampu bertahan lama walaupun tidak mendapatkan gaji sesuai UMR (Upah minimum regional).

\section{Kesimpulan}

\section{PENUTUP}

Berdasarkan hasil analisis dan pengujian dari tujuh hipotesis penelitian berdasarkan model teoritis yang diuji dengan kriteria goodness of fit untuk menjawab rumusan masalah penelitian, maka dapat diambil kesimpulan sebagai berikut :

1. Stres kerja berpengaruh negatif terhadap kepuasan dan kinerja karyawan. Artinya semakin tinggi stres kerja karyawan maka kinerjanya akan semakin turun. Begitu juga dengan kepuasannya akan menurun. Tingkat stres karyawan dalam perusahaan ini tinggi maka perlu segera diatasi dengan menurunkan tingkat stresnya sehingga kinerja karyawan akan dapat terus meningkat, dan bisa mencapai target.

2. Kedisiplinan tidak berpengaruh terhadap kepuasan kerja maupun kinerja karyawan. Kedisiplinan tetap perlu ditingkatkan, namun perlu memovitasi karyawan supaya kedisiplinannya yang dilakukan bisa digunakan untuk peningkatan kinerja karyawan. 
3. Kepuasan berpengaruh terhadap kinerja karyawan. perlu ditingkatkan rasa puas agar kinerja karyawan terus meningkat. Kepuasan bukan merupakan variabel pemediasi.

\section{Implikasi Teoritis}

Kepuasan kerja dan kinerja karyawan pada perusahaan ini dipengaruhi oleh stres dan employee engagement. Implikasi teoritis penelitian ini berkaitan dengan stres kerja, kedisiplinan, employee engagement, kepuasan dan kinerja dapat dijelaskan sebagai berikut :

a. Implikasi yang berkenaan dengan stres. Stres kerja merupakan ketidakmampuan karyawan dalam menghadapi berbagai tuntutan kerja karena karyawan tidak memiliki kemampuan untuk memenuhi tuntutan tersebut. Karyawan yang mengalami stres tinggi, maka kinerjanya juga akan semakin buruk atau menurun dan bila karyawan mengalami penurunan stres maka kinerjanya juga akan semakin membaik. Hasil penelitian ini memperkuat penelitian terdahulu yang dilakukan oleh Handoko (2008), Harianto, Wiguna, Rakhmad (2008), Dewi, Bagia, Susila (2014), Chandra (2012), Nur (2013), Usman, Bashir, Ramay (2010), Mansoor dkk (2011) bahwa stres kerja memiliki pengaruh negatif terhadap kinerja dan kepuasan kerja.

b. Implikasi yang berkenaan dengan kedisiplinan. Kedisiplinan merupakan kesediaan seorang karyawan untuk memenuhi segala peraturan yang ada dalam perusahaan dan norma-norma yang berlaku. Kedisiplinan juga meruapakan bentuk pengendalian diri agar karyawan tidak melanggar peraturan. Pada penelitian ini kedisiplinan terbukti tidak berpengaruh terhadap kinerja karyawan maupun kepuasan karyawan. Hasil penelitian ini sesuai dengan penelitian sebelumnya yang dilakukan oleh Arianto (2013) dan Sadiyo (2014) bahwa kedisiplinan tidak berpengaruh terhadap kinerja. Kedisiplinan tidak menjadi jaminan seorang karyawan memberi hasil kerja yang lebih baik.

c. Implikasi yang berkenaan dengan employee engagement. Employee engagement merupakan sesuatu yang dilakukan seorang karyawan melebihi apa yang diharapkan perusahaan, dimana karyawan bersedia untuk bekerja dengan rekan kerja untuk meningkatkan kinerjanya demi mencapai tujuan perusahaan. employee engagement adalah kontribusi lebih karyawan terhadap perusahaannya. Hasil penelitian ini membuktikan bahwa employee engagement berpengaruh terhadap kepuasan kerja dan kinerja. Hasil penelitian ini mendukung hasil penelitian sebelumnya yang dilakukan oleh Haerani (2012) dan Dajani (2015), bahwa employee engagement berpengaruh terhadap kinerja.

d. Implikasi yang berkenaan dengan kepuasan kerja karyawan. Kepuasan kerja adalah kondisi yang menyenangkan secara emosional yang berasal dari penilainnya terhadap pekerjaannya. Sehingga kepuasan ditunjukkan 
dengan perasaan puas dan tidak puas. Kepuasan berpengaruh terhadap kinerja, artinya bila kepuasan karyawan meningkat maka kinerja juga akan meningkat. Hasil ini sesuai dengan penelitian Adawiyah dan Siswanto (2015) bahwa Kepuasan berpengaruh terhadap kinerja.

e. Implikasi yang berkenaan dengan kinerja karyawan . Kinerja merupakan hasil baik secara kualitas dan kuantitas yang bisa dicapai oleh karyawan dalam bekerja. Sehingga hasil atau tingkat keberhasilan karyawan dalam bekerja bisa berbeda-beda tergantung tingkat kemampuannya. Kinerja karyawan dipengaruhi oleh stres kerja, employee engagement dan kepuasan

\section{Implikasi Manajerial}

Adapun implikasi manajerial dari hasil temuan penelitian ini untuk meningkatkan kinerja karyawan adalah sebagai berikut :

1. Meningkatkan kinerja karyawan maka dapat dilakukan dengan cara menurunkan stres.

Hal yang dapat dilakukan untuk mengurangi stres dan meningkatkan kinerja yaitu:

- Karyawan tetap diberikan fasilitas untuk mendengarkan musik, tapi untuk jenis lagu yang diputar sebaiknya dipilih jenis lagu-lagu yang dapat membangkitkan semangat karyawan.

- Sebaiknya diatur kembali waktu untuk mengatur jam shalat dan istirahat diluar waktunya sesuai ketentuan peraturan agar tetap kondusif.

- Diberikan pengajian dan tausiyah secara berkala dan teratur untuk memotivasi secara kejiwaan ( siraman ruhani). Diberikan paradigma dan wawasan yang lebih luas, bahwa bekerja bukan hanya untuk uang. Lebih dari itu, bekerja adalah bagian dari ibadah, dan sebagai bentuk nasionalisme dan patriotisme terhadap negaranya. Bekerja juga bukan merupakan beban, bukan merupakan keadaan yang menyedihkan sehingga tingkat stresnya bisa dikurangi.

- Perlu melakukan analisis dan evaluasi kinerja karyawan, sehingga bisa diterapkan Right man in the right job ( orang yang tepat pada pekerjaan yang tepat), sehingga hasil nya bisa lebih maksimal.

- Perlu dilakukan penggantian layout agar karyawan tidak merasa bosan dan karyawan bisa mempelajari hal yang baru serta bisa mengatahui bakat dan minat karyawan.

2. Meningkatkan kinerja karyawan, kedisiplinan perlu ditingkatkan. Kedisiplinan adalah sebagai alat untuk mengukur apakah peraturan sudah ditegakkan dengan benar. Berdasarkan hasil analisis hipotesa, bahwa kedisiplinan tidak berpengaruh terhadap kinerja. Karyawan memiliki disiplin yang tinggi karena takut denda dan gaji akan terpotong. Perlu dilakukan cara yang lain agar 
motivasi karyawan melakukan kedisiplinan adalah karena perlunya peningkatan kinerjanya. Adapun cara yang bisa dilakukan untuk peningkatan disiplin adalah dengan cara :

- Diperlukan evaluasi atau penilaian kerja secara teratur dan berkala untuk mengetahui kualitas karyawan.

- Perlu adanya evaluasi peraturan perusahaan sebagai alat pengendali karyawan agar motivasi karyawan untuk disiplin bukan semata-mata karena punishmentnya tapi justru lebih termotivasi untuk peningkatan kinerjanya dan kemajuan perusahaannnya.

3. Employee engagement berpengaruh secara langsung terhadap kinerja. Dengan meningkatkan employee engagement karyawan , maka kinerja karyawan juga akan terus meningkat. Untuk meningkatkan kinerja karyawan melalui employee engagement, maka perlu dilakukan hal- hal sebagai berikut :

- Perusahaan harus bisa menjaga kuantitas dan kualitas karyawan itu sendiri, artinya karyawan tidak banyak yang keluar dari perusahaan, namun karyawan harus terus bisa meningkatkan secara kualitas ketrampilannya. Perusahaan perlu memberikan motivation training dan pelatihan ketrampilan supaya kinerjanya semakin lebih baik.

- Karyawan yang bertahan cukup lama, mungkin menjadi lebih ahli pada bidangnya karena lamanya pengalaman, namun tidak menutup kemungkinan karena umur yang bertambah juga menurunkan kondisi fisik karyawan. Maka perlu dilakukan medical check-up secara rutin di perusahaan dan perlu disediakan obat-obatan atau vitamin untuk menjaga kesehatan dan kebugaran karyawan.

- Perlunya diikutsertakan BPJS bagi karyawan dan keluarganya. Bila kesehatan karyawan dan keluarganya terjaga maka karyawan akan lebih tenang dalam bekerja dan berusaha bekerja dengan lebih keras agar tidak diberhentikan karena merasa telah terjamin hidupnya dalam perusahaan tersebut .

4. Kepuasan bukan merupakan variabel intervening (pemediasi ) baik bagi stres, kedisiplinan atau employee engagement. Walaupun demikian, apabila dalam penelitian ini nilai pengaruh kepuasan pada perusahaan secara positif ditingkatkan atau naik maka kepuasan akan dapat menjadi variabel pemediasi bagi stres dan employee engagement. Sehingga implikasi manajerialnya dari penelitian untuk perusahaan adalah walaupun karyawan mengalami stres, namun perusahaan berusaha untuk meningkatkan kepuasan karyawan yang lebih tinggi , maka diharapkan akan meningkatkan kinerjanya.

Hal yang sama juga pada employee engagement, Apabila nilai kepuasan difokuskan untuk ditingkatkan akan dapat menjadi variabel pemediasi. Sehingga ketika employee engagement karyawan dalam kondisi apapun, namun jika nilai kepuasannya lebih tinggi akan mampu meningkatkan kinerjanya. Hal-hal yang 
perlu dilakukan perusahaan untuk meningkatkan nilai kepuasan karyawan adalah sebagai berikut :

- Memberikan sistem bonus atau diberikan kompensasi apabila karyawan dapat mencapai targetnya.

- Sebaiknya karyawan digaji berdasarkan hasil kerjanya. Bila gaji karyawan sama, namun karyawan memberikan hasil yang berbeda maka akan terjadi kesenjangan kinerja yang justru dapat menurunkan kinerja karyawan secara keseluruhan yang berarti secara otomatis menurunkan kinerja perusahaan.

- Diadakannya acara gathering secara bersama-sama akan menambah keeratan antara karyawan yang diharapkan mampu meningkatkan kerjasama dan kekompakan. Karyawan yang merasa lebih bahagia dengan pekerjaannya akan merasa lebih puas, dan diharapkan kinerjanya juga lebih baik.

\section{Keterbatasan Penelitian}

1. Hasil analisis dan penelitian hipotesa bahwa kedisiplinan berpengaruh terhadap kinerja karyawan tidak terbukti. Sedangkan menurut teori dan telaah pustaka bahwa kedisiplinan berpengaruh terhadap kinerja karyawan. Kemungkinan kesalahan dapat terjadi dalam penelitian ini dalam pengambilan data di lapangan dan dalam pembuatan pertanyaan untuk pengukuran penelitian.

2. Nilap P ( probabilitas ) dalam penelitian ini adalah 0,00 , sedangkan syarat untuk dilakukan analisis adalah nilai $\mathrm{P}$ sebesar 0,05 , pada penelitian ini nilai probabilitas selalu pada angka 0,00 karena probabilitas sangat sensitif pada jumlah sampel. Semakin besar jumlah sampel maka akan selalu menghasilkan nilai $\mathrm{P}$ yang signifikan. Namun itu tidak menjadi masalah, karena ukuran GOF bisa dilihat dari kriteria yang lainnya.

\section{Usulan Penelitian Mendatang}

1. Variabel Kedisiplinan yang tidak berpengaruh terhadap kinerja bisa menjadi acuan untuk dilakukan penelitian kembali di masa yang akan datang. Mengembangkan model dengan memasukkan variabel-variabel yang lain juga akan lebih baik.

2. Perlu dilakukan dalam jenis industri yang berbeda, tempat yang berbeda, atau kriteria responden yang berbeda karena perbedaan tempat dan responden akan memungkinkan untuk memberi hasil penelitian yang berbeda. Dimana hasil penelitiannya akan mempengaruhi kinerja karyawan dan kinerja perusahaan secara keseluruhan.

DAFTAR PUSTAKA

Adawiyah dan Siswanto. Stres Kerja, Pengaruhnya Terhadap Kinerja Karyawan Dengan Kepuasan Kerja Sebagai Variabel Mediasi. Jurnal El-Dinar , Vol. 3, No.1, Januari 2015. 
Arianto, D.A.N. 2013. Pengaruh Kedisiplinan, Lingkungan Kerja Dan Budaya Kerja Terhadap Kinerja Tenaga Pengajar. Jurnal Economia, Volume 9, Nomor 2, Oktober 2013, Hal:191-200

. Arsyenda, Yoga. 2013. "Pengaruh motivasi kerja dan disiplin kerja terhadap kinerja PNS (studi kasus:BAPPEDA kota Malang)". Jurnal Ilmiah. Malang: Fakultas ekonomi dan bisnis, Universitas Brawijaya.

Amstrong, Mischael.1999. Manajemen Sumber Daya Manusia. Terjemahan Sofyan Dan Haryanto. Jakarta : Pt. Elex Media Komputindo

Avolio, et al , 2004. Unlocking the mask: A look at the process by which authentic leaders impact follower attitudes and behavior. The Leadership Quarterly 15 (2004) $801-823$

Aprilia, D. Pengaruh Lingkungan Kerja Disiplin Kerja Dan Komitmen Organisasi Terhadap Kinerja Karyawann Pt. Indomulti Plasindo Di Kota Semarang. Ejurnal Fakultas Ekonomi dan Bisnis.

Ashar, S Munandar. (2001). Psikologi industri. Jakarta: universitas indonesia.

Bashir, Ramay. Impact of Stress on Employees Job Performance A Study on Bangking Sector of Pakistan. International Journal of Marketing Studies, Vol 2, No 1, May 2010.

Cataldo, P. (2011). Focusing on Employee Engagement: How to Measure It and Improve It.White Paper, UNC Kenan-F lagler Business School, UNC Executive Development, North Carolina.

Chandra, J. Pengaruh Stres Kerja Dan Kepuasan Kerja Terhadap Kinerja PT. Lie Fung Surabaya. Jurnal, 2012. Surabaya : Universitas Surabaya.

Cheema, Akram, Javed (2015). Employee Engagement and Visionary Leadership: Impact on Customer and Employee Satisfaction. Journal of Business Studies Quarterly 2015, Volume 7, Number 2 ISSN 2152-1034

Chiriyah, Siti. 2009. Pengaruh Disiplin Kerja Dan Komunikasi Terhadap Kepuasan Kerja Karyawan Pada Pt. Hamudha Prima Media Di Pajang Sukaharjo. Skripsi. Surakarta : UMS.

Cooper, Cary dan Straw, Alison. 1995. Stress Management Yang Sukses Dalam Sepekan. Jakarta : Kesaint Blanc.

Darmadi, Hamid. 2011. Metode Penelitian Pendidikan. Bandung: Alfabeta.

Dewi, Bagia dan Susila. Pengaruh Stres kerja dan Kepuasan Kerja Terhadap Kinerja Karyawan Pada Bagian Tenaga Penjualan (UD Surya Raditya Negara). E-Jurnal Bisma universitas pendidikan Ganesha vol. 2, 2014.

Ferdinand. 2014. Metode Penelitian Manajemen. Semarang : Universitas Diponegoro.

Federman, Bard. (2009). Employee Engagement: A Road For Creating Profits, Optimizing Perfomance, And Increasing Loyalty. SanFransisco: Jossey Bass.

Fisher, D. (1998). Effects of external and internal interruptions on boredom at work: two studies. Journal of Organizational Behavior : Australia. 
Ghozali. 2013. Model Persamaan Struktural Konsep Dan Aplikasi. Semarang : Universitas Diponegoro.

Gibbons, J. 2006, Employee Engagement: A Review of Current Research and its Implications, New York: The Conference Board, November.

Haerani, Siti . 2010. Employee Engagment Dan Pengaruhnya Terhadap Kinerja Departemen Process Plant PT.Inco Pasca Akuisisi. Makalah penelitian. Sulawesi Selatan : Universitas Hasanudin.

Handoko,T,Hani,2008.Manajemen Personalia Sumber Daya Manusia,Edhisi Kedua. Jogyakarta.Penerbit BPFE

Haryono. 2017. Metode SEM Untuk Penelitian Manajemen. Jakarta : Luxima Metro Media.

Harianto, F., Wiguna, P.A., \& Rakhmad, D. (2008). Pengaruh Stress Kerja, Motivasi Kerja, dan Gaya Kepemimpinan Terhadap kinerja tenaga Kerja Pada Proyek Mall Yani Golf di Surabaya. Jurnal IPTEK Vol.11, No.3.

Hasibuan, Malayu S. P. (2002). Manajemen Sumber Daya Manusia, Edisi Revisi. PT Bumi Aksara, Jakarta.

Hewitt, A. (2014). 2014 Health Care Survey. AON. Retrieved from http://www.aon.com/attachments/human-capital-consulting/2014Aon-HealthCare Survey.pdf.

Jellesma, F.C. \& Vingerhoets, A.J.J.M. (2012). Crying in middle childhood: A report on gender differences. Sex Roles, 67, 412-421. doi: 10.1007/s11199012-0136-4

Lamidi.2010.Efek Moderasi Kepemimpinan Pada Pengaruh Employee EngagementTerhadap Kepuasan Kerja.Jurnal Ekonomi dan Kewirausahaan.10(2):h:190-200.

Listianto, Tony dan Setiaji, Bambang, 2005. Pengaruh Motivasi, Kepuasan, Dan Disiplin Kerja Terhadap Kinerja Karyawan (Studi Kasus di Lingkungan Pegawai Kantor PDAM Kota Surakarta).

Leksono, Hendi. Kebosanan Kerja : Peningkatan Stres dan Penurunan Kinerja karyawan dalam Spesialisasi Pekerjaan. Jurnal JI Beka Vol.8, No 2, Agustus 2014.

Leksono, Sonny. Penelitian Kualitatif Ilmu Ekonomi : dari metodologi ke metode. Jakarta: PT Raja Grafindo Persada, 2014.

Luthans, Fred. 2006. Prilaku Organisasi edisi 10. Yogyakarta: ANDI Yogyakarta. Mangkunegara dan Octorend. Effect of work Discipline, Work Motivation and Job satisfaction on Employee Organizational Commitment in the Company ( Case Study in PT. Dada Indonesia). Universitas Journal of Management vol. 3, no.8, 2015.

Mangkunegara, Anwar. 2009. Manajemen Sumber Daya Manusia Perusahaan. Bandung: PT Remaja Ros Dakarya.

Mangkunegara, Anwar . 2002. Perilaku Konsumen, PT. Rafika Aditama, Bandung. 
Mansoor, Fida, Nasir dan Ahmad. The Impact of Job Stress on Employee Job satisfaction A Study on Telecommunication Sector of Pakistan. Journal of Business Studies Quarterly, Vol.2, No.3, 2011.

Mathis Robert L. dan Jackson John H. 2006, Human Resource Management, alih bahasa. Salemba Empat. Jakarta.

Mondy, R. Wayne. 2008. Manajemen Sumber Daya Manusia. Jakarta: Penerbit Erlangga.

Mansoor, M., Fida, S., Nasir, S. and Ahmad, Z. (2011) The Impact of Job Stress on Employee Job Satisfaction: A Study on Telecommunication Sector of Pakistan. Journal of Business Studies Quarterly, 2, 50-56.

Murti dan Srimulyani. Pengaruh Motivasi Terhadap Kinerja Pegawai Dengan Variabel Pemediasi Kepuasaan Kerja Pada PDAM Kota Madiun. Jurnal Riset Manajemen dan Akuntansi vol.1, no1, Februari 2013.

Macey et al (2009) .Employee Engagement A review of current thinking. INSTITUTE FOR EMPLOYMENT STUDIES Mantell Building University of Sussex Campus Brighton BN1 9RF UK ISBN 9781851844210

Naqvi, Khan, Kant dan Khan. Job Stress and Employees' Productivity : Case of Azad Kashmir Public Health Sector. Interdisciplinary journal of Contemporary Researc in Business vol 5, no. 3, July 2013.

Nur, Saina. Konflik, Stres Kerja Dan Kepuasan Kerja Pengaruhnya Terhadap Kinerja Pegawai Pada Universitas Khairun Ternate. Jurnal Emba V01.1, No. 3, September 2013.

Nurbaity dan Sulistyo. Pendekatan Engagment dalam Membangun Kinerja. Jurnal Ekonomi Bisnis Vol.14, No.2, januari 2013.

Nurhendar, Siti. 2010. Pengaruh Stres Kerja Dan Semangat Kerja Terhadap Kinerja Karyawan Bagian Produksi (Studi Kasus Pada CV. Aneka Ilmu Semarang). Tesis. Semarang :Universitas Diponegoro.

Pediwal, G. L. 2011. Excessive stress and its impact on employee behavior. Journal of Global Economy., 1(1): 13-40.

Prawirosentono, Suryadi. 1999. Kebijakan Kinerja Karyawan. Yogyakarta : BPFE.

Prihantoro, A. Peningkatan Kinerja Sumber Daya Manusia Melalui Motivasi, Disiplin, Lingkungan Kerja Dan Komitmen. Jurnal Unimus Vol.8, No.2, Maret 2012.

Putri, Baga dan Sunarti. Employee Engagment, Lingkungan Sosial dan Kinerja karyawan di PT BRI Tbk, Kantor Cabang Bogor Dewi Sartika. Journal IPB vol. 10, No.2, September 2015.

Rachmawati. Employee Engagment Sebagai Kunci Meningkatkan Kinerja Karyawan (International Journal Review) Vol.6, No.12, Desember 2013.

Ramadhan dan Sembiring. Pengaruh Employee Engagment Terhadap Kinerja Karyawan Di Human Capital Center Pt. Telekomunikasi Indonesia, Tbk. Jurnal Manajemen Indonesia vol.14, No.1, April 2014. 
Rivai dan Basri. 2005. Perfomance Apraisal : Sistem Yang Tepat Untuk Menilai Kinerja Karyawan Dan Meningkatkan Daya Saing Perusahaan. Jakarta : PT. Raja Grafindo Persada.

Robbins, Stephen P. (2006). Perilaku Organisasi. Edisi kesepuluh. Jakarta: PT Indeks Kelompok Gramedia.

Robbins, Stepent P. dan Timoty A. Judge. 2008. Perilaku Organisasi. Jakarta:Salemba Empat.

Robertson, I. T., Birch, A. J., \& Cooper, C. L. (2012). Job and Work Attitudes, Engagement and Employee Performance: Where does Psychological WellBeing Fit in? Leadership \& Organization Development Journal, 33(3), 224232.

Robinson, D., Perryman, S., dkk. 2004. The Drivers of Employee Engagement Report 408, Brington: Institude for Employement Studies.

Sadiyo, 2014, Uji Korelasi Motivasi dan Disiplin Kerja terhadap Kinerja Guru Dimoderasi Kepemimpinan Kepala Sekolah, Jurnal Pendidikan, STMIK AKI Pati, Vol.1, No.1, Hal. 39-48.

Setiawan, Ivan Aries dan Ghozali,2006. "Akuntansi Perilaku”, Edis, Badan Penerbit Universitas Diponegoro, Semarang.

Siti Haerani.2004. Pengaruh Perubahan Organisasi terhadap Peluang Karier, Stres, Komitmen Oranisasi, Kepuasan Kerja Karyawan Studi Pada Beberapa Perusahaan Yang Melakukan Marger di kota Makasar. Disertasi.

Smythe, John. 2007. The CEO (Chief Engagement Officer): Turning Hierarchy Upside Down To Drive Performance. England: Gower Publishing Com.

Sugiyono.2010. Metode Penelitian Pendidikan. Bandung : Penerbit Alfabeta.

Sutrisno.2014. Pengaruh Stres Kerja Terhadap Kinerja Karyawan (Studi Kasus Di Man Demak ). Skripsi. Yogyakarta : Universitas Sunan Kalijaga.

Sutrisno Edy, 2012. Manajemen Sumber Daya Manusia. Jakarta: Kencana

Tampi, Pio dan Tampi. Pengaruh Stres Kerja Terhadap Kinerja Karyawan Pada PT.BRI Dana Raya Manado. Sulawesi Utara.

Thaief, Baharuddin, Priyono Dan Idrus. Effect Of Training, Compensation And Work Discipline Againt Employee Job Performance. Review of European studies, Vol.7, No.11, 2015.

Wellins, R., Concelman, J. (2005), Creating a culture for engagement, diunduh http://www.talentmgt.com/articles/creating_a_culture_for_engagement .

Wiley \& Blackwell.2009. Employee Engagement : Tools for Analysis, Practice, and Competitive Advantage. 